\title{
潮位による影響及び時間的異質性を考慮した 汀線変動モデルの構築と将来予測
}

\section{Development of Shoreline Change Model Considering Time Heterogeneity and Tidal Impact and Prediction of Future Shoreline Position under Global Climate Change}

\author{
伴野雅之 ${ }^{1}$ ・栗山善昭 ${ }^{2}$
}

\author{
Masayuki BANNO and Yoshiaki KURIYAMA
}

\begin{abstract}
This study developed the shoreline change model using a random effect of time heterogeneity which was caused by the influence of unmeasured variables, and the model could estimate the effects of the wave energy and the tidal level. The developed model predicted the future shoreline positions from 2008 to 2095 with assumptions of sea level rises and wave climate changes under the global climate changes on the Hasaki coast in Japan, facing the Pacific Ocean. The simulation results showed that the foreshore would be eroded approximately $20 \mathrm{~m}$ and the shoreline position would retreat approximately $40 \mathrm{~m}$ due to global climate change by the end of this century.
\end{abstract}

\section{1.はじめに}

将来予測されている地球温暖化に伴う海面上昇や台風 等の巨大化は海岸侵食の深刻化を招き, 海浜の有する防 災や環境上の機能の低下を引き起こすことから，海浜の 長期安定性を考慮した対策が必要とされている。実際に， ここ数十年間の海面上昇はIPCCの予測結果よりも大き い傾向にあることが示されており（Rahmstorf et al., 2012), 海岸侵食のより一層の深刻化が鷍念される。ま た，森ら（2009）は今世紀末の日本近海における波高の 平均值は減少する一方で, 最大波高は増加し, 気候が極 端化すると予測しており，これに対応して海浜地形は現 在と比較してよりドラステイックに変動すると考えられる.

このような将来の外力変化に対する海浜地形の長期的 変化を予測することは将来の海岸侵食対策を考える上で 非常に重要であり，その予測には波浪エネルギーの変化 のみならず海面上昇による地形変化への影響を評価でき るモデルの開発が必要である。例えばBruun（1962）は 海面変化に応じて平衡断面が遷移することで海浜変形が 生じる，いわゆるBruun則を示し，長期の海面変化に対 する地形変化を求めることを可能にした。 しかしながら, Bruun則による地形変化は平均波浪に対する平衡状態を 仮定したものであり，海面上昇と同時に時々刻々変化す る波浪における非平衡状態での地形変化を評価すること はできない.

一方で，地形変化は様々な影響因子が複雑に影響しあ う現象であるけれども, 現実にはそのすべての因子を観

$\begin{array}{lll}1 \text { 正会員 } & \text { 修(工) } & \begin{array}{l}\text { (独法)港湾空港技術研究所 沿岸環境研 } \\ \text { 究領域沿岸土砂管理研究チーム研究官 }\end{array} \\ 2 \text { 正会員 } & \text { 博(工) } & \text { (独法)港湾空港技術研究所 特別研究官 }\end{array}$

測し，モデルへ反映させることは難しい．時系列データ において，そのようなモデルに反映できない未知変数は 時間的に異なり，しばしば目的としている観測值のばら つきを増大させる。このような未知変数に起因した観測 值にばらつきを生じさせる影響のことを統計学的にラン ダム効果 (Random effects) と呼び, このランダム効果を 考慮した統計モデルを一般化線形混合モデル（GLMM） と呼ぶ（例えば，久保，2012）。時系列データにおける 上述のようなランダム効果は「時間的異質性」と呼ぶこ とができ，時間的異質性を有する現象をモデリングする 際には，ランダム効果を考慮しなければモデルパラメー 夕を正確に推定できないという問題が生じる.

そこで本研究では, 波浪エネルギーを主な汀線変動の 外力としたモデルを発展させ，潮位による影響と時間的 異質性を考慮した長期的な予測が可能な汀線変動モデル を構築した。具体的には, 波浪エネルギーに対する汀線 の応答特性に潮位や未知変数が与える影響を考慮したモ デルであり, 統計的手法を応用し, 未知変数による影響 をランダム効果とした線形混合モデルである。また構築 されたモデルを用い, 地球温暖化に伴う海面上昇や波浪 条件の変化による汀線位置の将来予測を行った。

なお, 本研究における汀線変動モデルは岸沖方向に一 次元のモデルであり, 汀線位置とは現在のH.W.L.の地盤 高の岸沖位置である。つまり, 海面上昇によって汀線位 置の基準となる地盤高は変化させないことから, 本研究 における汀線位置の定義はいわゆる水際ではなく, 汀線 変動は前浜の侵食や堆積の状況を表す指標として取り扱 うことができる(図-1). 


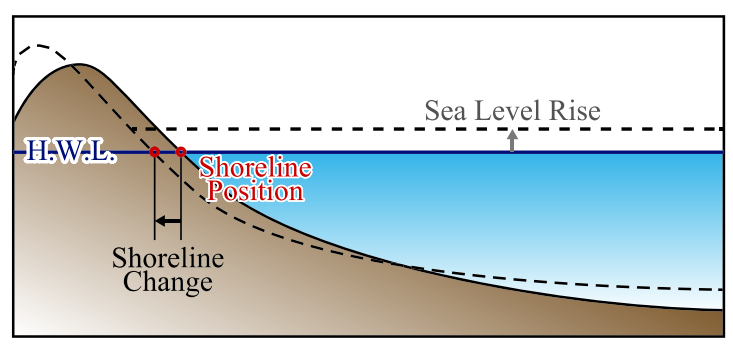

図-1 本研究における汀線位置の定義

\section{2. モデルの構築}

\section{（1）現地観測データ}

本研究で取り扱うデー夕は伴野・栗山（2011）で用い られたデー夕と同様の方法で取得されたものであり, 茨 城県波崎海岸に位置する波崎海洋研究施設ならびにその 近傍で得られたH.W.L.の汀線位置，沖波エネルギーフラ ックス, 潮位の日デー夕 (以下, HORSデータ) である. 本研究で用いる汀線変動量は 1 日当りの汀線の移動量と し，沖向きの前進を正，岸向きの後退を負とした．なお， 本研究では1986年3月12日から 2007 年 12 月 31 日までの 22 年間をデータの対象期間とした。

\section{(2) 分布型の近似}

汀線変動は主に波浪エネルギーによって生じる現象で あることから, 構築する汀線変動モデルも波浪エネルギ 一を基礎としたものである必要がある。一方で，永井ら （1998）が波浪エネルギーの発生確率分布に対して適用 したように，有義波波高の二乗と有義波周期の積で求め られる沖波エネルギーフラックスの発生確率分布は中心 極限定理より対数正規分布に近似できるが，汀線変動量 の発生確率分布は正規分布の負值側の裙野が長くなった 分布型となっている（図-2 (a), 図-2 (b)). 目的変数と 説明変数の分布型が全く異なる場合, 線形でモデリング すると大きな誤差が生じ，精度の低いモデルとなってし まうことから，変数変換により目的変数と説明変数の分 布型を近似させる必要がある。

そこで本研究では沖波エネルギーフラックスに対して 対数変換を行うことで正規分布に近似し, さらに対数值 を二乗することで汀線変動量の発生確率分布に分布型を 近似した変数（図-2 (c)）を汀線変動モデルに用いること とし, 目的変数である汀線変動量が沖波エネルギーの対 数の二乗值と定数（切片）によって表される式(1)を汀 線変動モデルの基礎式とした。

$$
\frac{d y}{d t}=\alpha_{1}(\log E f)^{2}+\alpha_{2}+\varepsilon
$$

ここで, $d y / d t$ : 汀線変動量, $E f$ : 沖波エネルギーフラッ クス， $\alpha_{1}, \alpha_{2}$ : 係数， $\varepsilon$ : 誤差である。なお，モデル内 の変数に $(\log E f)^{2}$ を用いたことで，本モデルは沖波エネ
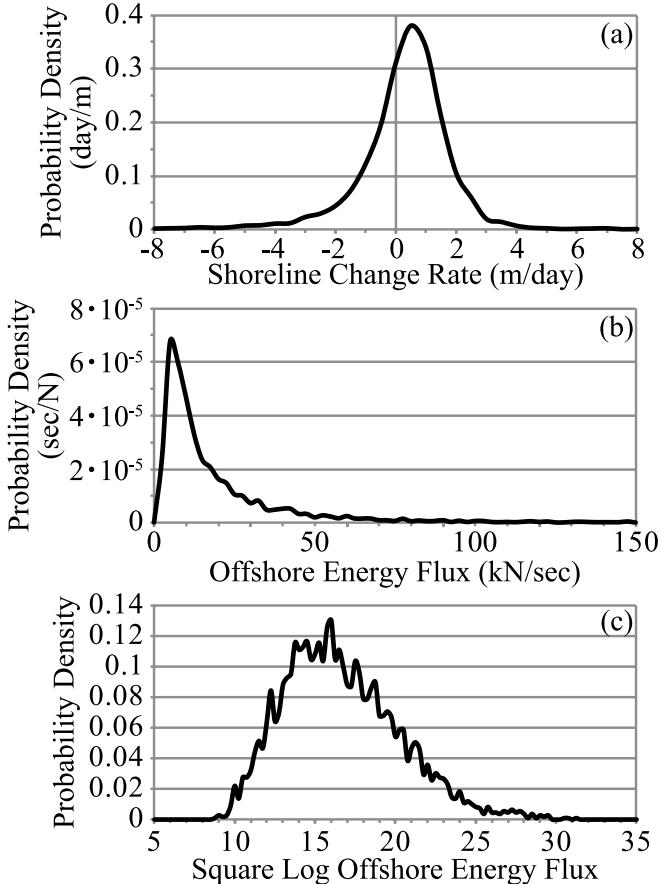

図-2 各変数の確率分布（a）汀線変動量，（b）沖波エネルギ ーフラックス，(c) 沖波エネルギーフラックスの対数の 二乗値

ルギーフラックスの増加に対して, 汀線後退量は増加す るが，その増加量は徐々に小さくなる傾向を表す。

(3) 汀線応答に影響を与える変数の導入

沖波エネルギーフラックスに対する汀線の応答は一意 的なものではなく，例えばその時の潮位や汀線位置に応 じて変化する。つまり，作用する波浪エネルギーが同じ であっても，潮位が高い場合や汀線位置が既に前進した 位置にある場合には，より侵食が生じやすくなることが 推測される。このような潮位や汀線位置といった変数は 直接的に汀線変動を引き起こす外力ではないけれども, 波浪エネルギーに対する汀線の応答に影響をあたえるこ とから, 式(1)における係数 $\left(\alpha_{1}, \alpha_{2}\right)$ を変動させるも のであると考えることができる，本研究では，汀線の応 答に影響を与える変数として潮位及び汀線位置を考慮 し，その影響が線形結合で表すことができると仮定し， 式(1)を式(2)へと発展させた。

$$
\begin{aligned}
\frac{d y}{d t}=\left(\beta_{1}+\beta_{3} y+\beta_{5} \eta_{\text {ave }}\right)(\log E f)^{2} & \left(\beta_{2}+\beta_{4} y+\beta_{6} \eta_{\text {ave }}\right)+\varepsilon
\end{aligned}
$$

ここで, $y$ : 汀線位置, $\eta_{a v e}$ : 平均潮位, $\beta_{1}, \beta_{2}, \beta_{3}, \beta_{4}$, $\beta_{5}, \beta_{6}:$ 係数である.

\section{（4）時間的異質性の考慮}

本研究における時間的異質性とは, 潮位や汀線位置が 
波浪エネルギーに対する汀線の応答に影響を与えたよう に，未知変数による影響で年によって汀線の応答が異な ることを表したものである。最終的に本研究で構築した 汀線変動モデルは式(2)の線形結合に時間的異質性であ るランダム効果を加えた式(3)の一般化線形混合モデル へと拡張したものである.

$$
\begin{aligned}
\frac{d y}{d t}=\left(\beta_{1}+\beta_{3} y+\right. & \left.\beta_{5} \eta_{\text {ave }}+r_{1}\right)(\log E f)^{2} \\
& +\left(\beta_{2}+\beta_{4} y+\beta_{6} \eta_{\text {ave }}+r_{2}\right)+\varepsilon
\end{aligned}
$$

ここで $r_{1}, r_{2}$ : 年による時間的異質性（ランダム効果） を表すパラメーターであり，年ごとに正規分布（平均 0 , 分散 $\left.\sigma^{2}\right)$ に従って值が変化するものである.ランダム効 果は一定值として推定されるものではなく, 効果のばら つきである分散 $\sigma^{2}$ のみによって表される確率分布であ る。なお，一般に時系列デー夕におけるランダム効果は その時間区切りを短くすればするほど分散が大きくな り，モデルの実測值への当てはまりは解析的には良くな る、しかしながら, 分散が増大することで将来の予測值 に対する不確実性も増大することになるため，実用上は 単純に時間区切りを短くすることには意味が無い，その ため，目的や実状に合わせた複数の時間区切りのランダ ム効果を同時にモデル内に考慮し，モデルを評価する必 要があるが, 本研究では, 過度なパラメー夕の推定の複 雑化を避ける必要があること, 長期的な汀線変動の将来 予測を対象とすることから, 年による時間区切りのランダム 効果（年の時間的異質性）のみを考慮することとした.

\section{（5）モデルパラメータの推定とモデルの精度}

本モデルの係数決定にはHORS デー夕を用い, $\varepsilon か ゙$ 正 規分布に従うとし，最尤推定法を用いた。なお，誤差の 増大を防ぐため，1986年から2007年のデータの内，汀線 位置の測量間隔が36時間以内のデー夕のみを係数決定に 用いた $(n=4361)$. ランダム効果 $r$ は年を一つのグループ とし，その分散 $\sigma^{2}$ のを最尤推定した。なお， $r_{1}$ と $r_{2}$ は 二変量正規分布として与えた．推定された各パラメータ の影響度を評価するために，上述の倸数決定用デー夕を 乗じることで, 各パラメータを汀線変動量の次元で示し, そのばらつきを比較した（図-3)。ばらつきの大きさは汀 線変動への影響度を表すものであり, ランダム効果のば らつきは，その他のパラメータのばらつきに対して比較 的大きいことから，本モデルに打いてはランダム効果の 影響が比較的大きいことが示された.

本モデルの汀線位置の推定精度を検証するために，推 定されたモデルを用い，1986年から2007年の日々の汀線 位置を追算した（図-4）。追算値と実測值の決定係数は 0.68であり，この值は伴野・栗山（2011）の重回帰モデ ルによる追算結果よりも大きく, 十分な推定精度を有し

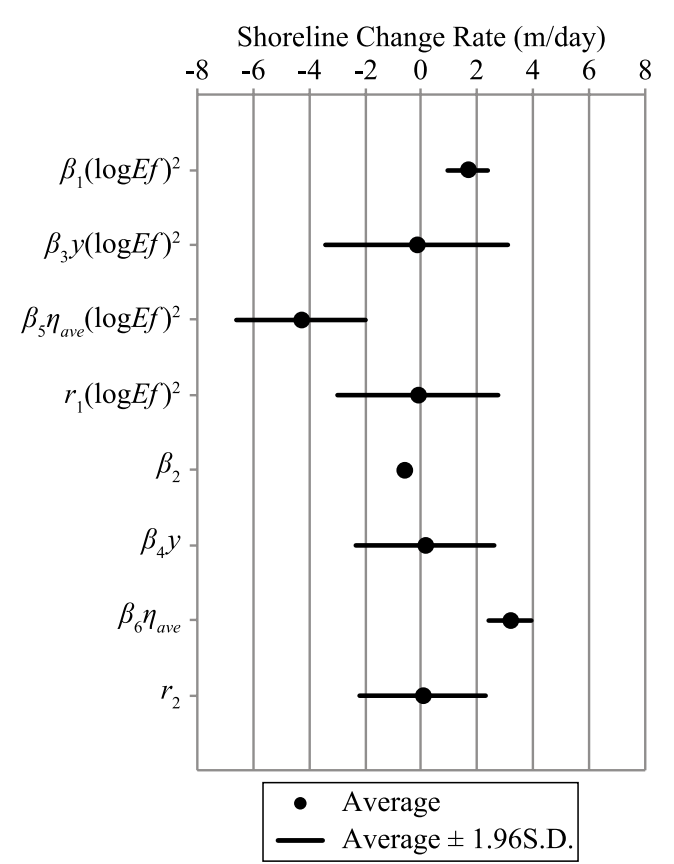

図-3 モデル構成要素の值のばらつき

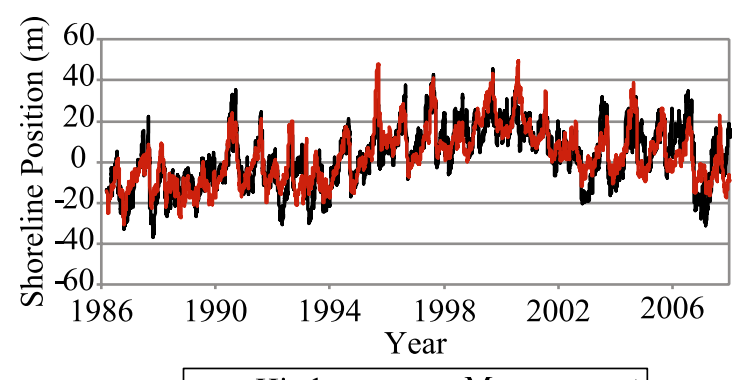

— Hindcast - Measurement

図-4 構築されたモデルを用いた汀線位置の追算結果

ていることが示された．また，本モデルはランダム効果 によって将来の不確実性を考慮できることから，将来に おいて 1986年から 2007年に起こった現象では説明でき ない何らかの極端な現象が生じない限り，本モデルは十 分な精度と安定性を有した将来予測計算が可能であると 考えられる。

\section{3. 将来予測}

得られた汀線変動モデルを用い，海面上昇と波高の変 化シナリオに応じた2008年から 2095年までの波崎海岸 に扔ける汀線位置の変動を将来予測した。予測計算にお いてはランダム効果を最尤推定された分散を有した正規 乱数として与えたモンテカルロ・シミュレーションを 10,000 回繰り返した.

シナリオは A：海面上昇が現在までの実測速度（4.8 $\mathrm{mm} / \mathrm{year}$ ) で生じる場合, B：海面上昇速度がIPCC AR4 
表-1 将来予測に用いたシナリオ

\begin{tabular}{c|c|c}
\hline Scenario & $\begin{array}{c}\text { Sea Level Rise } \\
\text { Rate }\end{array}$ & $\begin{array}{c}\text { Wave Climate } \\
\text { Change }\end{array}$ \\
\hline I & $\begin{array}{c}\text { A } \\
(4.8 \mathrm{~mm} / \text { year })\end{array}$ & - \\
\hline II & $\begin{array}{c}\text { A } \\
(4.8 \mathrm{~mm} / \text { year })\end{array}$ & $\begin{array}{c}\text { C } \\
\text { (Mori et al. (2009)) }\end{array}$ \\
\hline III & $\begin{array}{c}\text { B } \\
(4.8 \mathrm{~mm} / \text { year+ } \alpha t)\end{array}$ & - \\
\hline IV & $\begin{array}{c}\text { B } \\
(4.8 \mathrm{~mm} / \text { year }+\alpha t)\end{array}$ & $\begin{array}{c}\text { C } \\
\text { (Mori et al. (2009) })\end{array}$ \\
\hline
\end{tabular}

の最大予測量に従い，現在のものよりも徐々に早くなる 場合，C：森ら（2009）の将来の波高予測に基づき将来 の波高が変化する場合（平均值の減少, 最大波高の増加） を組み合わせたものとした（表-1）。具体的には，シナリ オデー夕は1986年から 2007 年までの 22 年間の実測の波 高及び潮位を将来の 22 年毎に繰り返したものを基本と し，シナリオ $\mathrm{A} に$ 関しては海面上昇のトレンドを考慮し， 潮位に対し海面上昇分を補正した。シナリオBに関して は，海面上昇トレンドとして，1995年から 2095年の海面 上昇量が IPCC AR4（2007）の全球平均海面上昇量の全 シナリオの最大予測值である $59 \mathrm{~cm}$ となるように，2008 年以降の海面上昇速度をシナリオ $\mathrm{A}$ の海面上昇速度の $4.8 \mathrm{~mm} / \mathrm{year}$ から線形的に加速させた潮位を用いた．シナ リオCに関しては，波浪の周期は変化させずに波高の変 化のみを考慮し，対応する沖波エネルギーフラックスを 計算した。2008年から 2029年の波高は変化させずに現状 と同じ波高とし，それ以降は 22 年毎に波高の平均值を $1 \% ， 2 \% ， 3 \%$ 減少，極值波高を $5 \% ， 10 \% ， 15 \%$ 増加させ た沖波エネルギーフラックスを用いた。つまり，現在の 沖波エネルギーフラックスの発生確率分布の平均值 $\mu$ を それぞれ $0.99^{2} \mu, 0.98^{2} \mu, 0.97^{2} \mu$ とし, 超過確率 $1 \%$ の值 が現在の $1.05^{2}$ 倍， $1.10^{2}$ 倍，1.15 倍となるように分散を 調整した将来の沖波エネルギーフラックスの発生確率分 布を用い, 将来の值を求めた.

図-5にシナリオを用いた将来予測結果，表-2に各シナ リオの 2074 年から 2095 年の最頻值と超過確率 $5 \%$ 值, 非 超過確率 5\%值を示す. 現状の海面上昇トレンドが継続 するとしたシナリオ I では今世紀末の汀線位置の最頻值 は-16mであり，シナリオ吕での海面上昇速度が加速した 場合には-19mまで後退する１986年から 2007 年の平均 汀線位置は $2.4 \mathrm{~m}$ であったことから, 将来の海面上昇によ って岸沖方向に約 $20 \mathrm{~m}$ 程度の海岸侵食が前浜に生じると 推測された.

一方で，海面上昇と同時にシナリオ II ， IVにおける波 高の変化を考慮した場合，波高の変化を考慮していない 場合（シナリオ I， II）と比較して，最頻值はほとんど 変化がなく, 非超過確率 $5 \%$ 值はわずかに後退すること
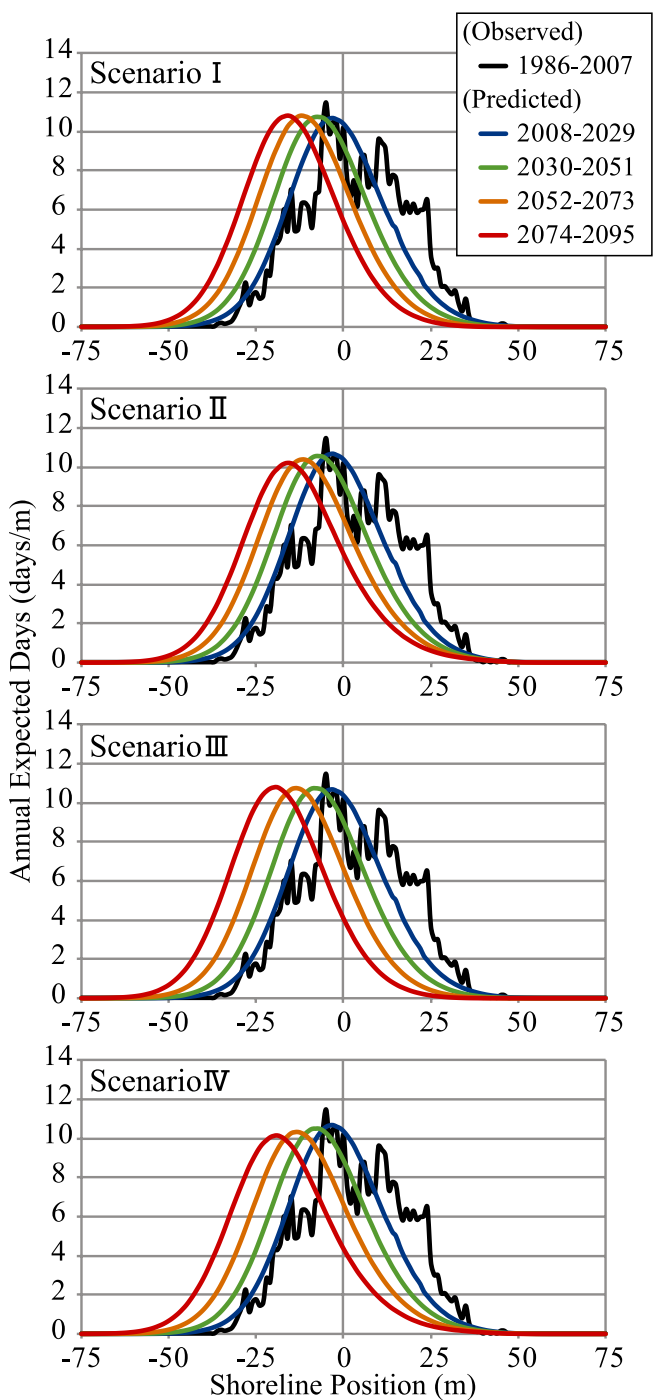

図-5 各シナリオにおける汀線位置の年間期待日数分布の将 来変化

が示された.一方, 超過確率 $5 \%$ 值は $5 \mathrm{~m}$ 程度前進するこ とが示された。すなわち，将来の波浪条件の変化によっ ては汀線が大きく後退することはなく, むしろ汀線の前 進する確率が上昇すると考えられる。このような結果が 得られた理由は, 最大波高の増加による影響は頻度が少 ないことや波高の増加に対する汀線の応答が非線形であ ることから限定的となる一方で, 波高平均值の減少によ って汀線が前進しやすくなるためであると考えられる.

\section{4. 本モデルとBruun則との比較}

ここで，将来の海面上昇に伴う，本モデルとBruun則 による汀線の後退量の比較を行う. Bruun則は, 将来の 海面上昇による汀線後退量を検討する上で比較的多く用 いられてきたものである（例えば，吉田ら，2012）。こ 
表-2＼cjkstart各シナリオにおける2074年～2095年の汀線位置 （5\%非超過確率值，最頻值，5\%超過確率値）

\begin{tabular}{c|c|c|c}
\hline Scenario & $\begin{array}{c}\text { Non-exceedance } \\
\text { Probability (5\%) } \\
\text { Position }\end{array}$ & Mode Position & $\begin{array}{c}\text { Exceedance } \\
\text { Probability (5\%) } \\
\text { Position }\end{array}$ \\
\hline I & $-38 \mathrm{~m}$ & $-16 \mathrm{~m}$ & $9 \mathrm{~m}$ \\
\hline II & $-39 \mathrm{~m}$ & $-16 \mathrm{~m}$ & $14 \mathrm{~m}$ \\
\hline II & $-42 \mathrm{~m}$ & $-19 \mathrm{~m}$ & $5 \mathrm{~m}$ \\
\hline IV & $-43 \mathrm{~m}$ & $-19 \mathrm{~m}$ & $10 \mathrm{~m}$ \\
\hline
\end{tabular}

こで, Bruun則における汀線とはいわゆる水際であり, 海面の上昇とともに汀線位置の基準となる地盤高が変化 する点に注意が必要である.

Bruun則を用いた汀線後退量の計算にはバーム高さ $B h$, 土砂の移動限界水深 $h_{c}$, バーム頂部から移動限界水深ま での水平距離 Lを用いた平均海底勾配が必要となり, 本 研究においては $B h=2.5 \mathrm{~m}, h_{c}=8 \mathrm{~m}$ (宇多, 1997), $L=900 \mathrm{~m}$ とし, 波崎海岸に押ける平均海底勾配は $1 / 86$ であると仮 定した。この仮定のもとBruun則を用い，シナリオIII 同じ $59 \mathrm{~cm}$ の海面上昇による汀線後退量を計算すると, $51 \mathrm{~m}$ 算出された.

一方で本モデルのシナリオ III の結果（2074年から 2095

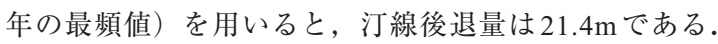
しかしながら，本モデルの汀線位置の定義は前述したよ うに現在のH.W.L.の地盤高の岸沖位置であり, 海面上昇 による水際の後退量を含んでいないため, 単純にBruun 則の結果と比較できない，そこで海面上昇により前浜勾 配が変化しないと仮定し, 前浜勾配を実測值に基づき 1/35 として, 海面上昇による水際の後退量を考慮すると, 本モデルによる地形変化と水際の後退を足しあわせた汀 線変化量は $42 \mathrm{~m}$ と算出された。本モデルによる後退量は Bruun則よりも $20 \%$ 程度小さいけれども, シナリオ IIIの 結果は2074-2095年の最頻值であり, 海面上昇量が $59 \mathrm{~cm}$ に達していない期間のデータを含むことから，実際には 扮抢よそ同程度の汀線後退量となると考えられる。すな わち，本モデルはBruun（1962）が示したメカニズムを 考慮できている上, 平衡状態に打ける汀線位置のみなら ず，時々刻々と変化する波浪に打ける非平衡状態での地 形変化を考慮できるモデルであることから，将来におけ る極值波浪による汀線の後退量等の検討も可能であり， 非常に汎用性が高いモデルであると考えられる。

\section{5. おわりに}

本研究では, 波浪エネルギーに対する汀線の応答特性 に及ほす「潮位の影響」及び未知変数に起因した影響で ある「時間的異質性」を考慮した精度の高い汀線変動予 測モデルを構築した。本モデルは将来の海面上昇による
影響を考慮できる上，時間的異質性を将来の不確実性と して考慮して計算することができる，本モデルを用いて 将来の海面上昇抢よび波高の変化シナリオによる波崎海 岸に抢ける汀線位置の将来予測計算を行った結果，将来 の海面上昇及び波浪の変化により汀線は後退し, 岸沖方 向に約 $20 \mathrm{~m}$ 近い前浜の侵食が生じると考えられる.また, 将来の海面上昇が汀線の大幅な後退を引き起こす要因で ある一方で, 将来の波高の増大による汀線の後退量は小 さく, 波高平均值の減少により汀線は前進しやすくなる と考えられる。ささらに, 海面上昇 (IPCC AR4の予測) に伴う地形変化に加え, 水際の後退を考慮した今世紀末 の汀線の後退量を算出した結果, 後退量の最頻值は $42 \mathrm{~m}$ となり, Bruun則により算出した汀線の後退量と㧍掞よ そ同程度であることが示された。

謝辞：本研究で使用した地形断面デー夕は独立行政法人 港湾空港技術研究所沿岸土砂管理研究チーム（旧漂砂研 究室）によって観測されたものである。また，波浪及び 潮位デー夕は国土交通省港湾局により提供されたもので ある. 本研究を進めるにあたって, 九州大学大学院 橋本 典明教授から様々なアドバイスを頂いた。また，国土交 通省港湾局 細川真也氏，中電技術コンサルタント株式会 社 田多一史氏, (独) 港湾空港技術研究所 渡辺謙太氏と は有益な議論を行った。ここに記し感謝の意を表する。

\section{参 考 文 献}

宇多高明（1997） 日本の海岸侵食, 山海堂, 442p.

久保拓弥 (2012) : デー夕解析のための統計モデリング入門一 般化線形モデル・階層ベイズモデル・MCMC, 岩波書店, $272 \mathrm{p}$.

永井紀彦・渡邊 弘・川口浩二（1998）：長期波浪観測結果に 基づく我国沿岸の波パワー出現特性の検討, 港研資料, No.895, pp.1-26.

伴野雅之・栗山善昭（2011）：重回帰モデルによる長期汀線変 動に対するバー及び潮位変動の影響評価, 土木学会論文 集B2 (海岸工学), Vol.67, No.2, pp.501-505.

森信人・岩嶋亮太・安田誠宏・間瀬 肇・ Tracey H. Tom(2009)：地球温暖化予測に基づく全球の海上風・波浪 の将来変化予測, 土木学会論文集 B2 (海岸工学), Vol.65, No.1, pp.1271-1275.

吉田 惊・有働恵子・真野 明（2012）：日本の5海岸におけ る過去の長期汀線変化特性と気候変動による将来の汀線 変化予測, 土木学会論文集B2 (海岸工学), Vol.68, No.2, pp.1246-1250.

Bruun, P. (1962) : Sea level rise as a cause of shoreline erosion, Journal of the Waterways and Harbors Division, Proc. ASCE, Vol.88, WW1, pp.117-130.

IPCC AR4(2007) : IPCC fourth assessment report, http://www. ipcc.ch/, 2013/5/1

Rahmstorf, S., G. Foster and A. Cazenave(2012) : Comparing climate projections to observations up to 2011, Environ. Res. Lett., Vol.7, 044035, pp.1-5. 